\title{
Zooshikella harenae sp. nov., Isolated from Pacific Oyster Crassostrea gigas, and Establishment of Zooshikella ganghwensis subsp. marina subsp. nov. and Zooshikella ganghwensis subsp. ganghwensis subsp. nov.
}

\author{
Hani Pira ${ }^{1}$, Chandra Risdian ${ }^{1,2}$, Peter Kämpfer ${ }^{3}$, Mathias Müsken ${ }^{4}$, Peter J. Schupp ${ }^{5}\left(\mathbb{D}\right.$ and Joachim Wink ${ }^{1, *} \mathbb{D}$ \\ 1 Microbial Strain Collection (MISG), Helmholtz Centre for Infection Research (HZI), \\ 38124 Braunschweig, Germany; Hani.Pira@helmholtz-hzi.de (H.P.); \\ Chandra.Risdian@helmholtz-hzi.de (C.R.) \\ 2 Research Unit for Clean Technology, National Research and Innovation Agency (BRIN), \\ Bandung 40135, Indonesia \\ 3 Institut für Angewandte Mikrobiologie, Justus-Liebig-Universität Giessen, 35392 Giessen, Germany; \\ peter.kaempfer@umwelt.uni-giessen.de \\ 4 Helmholtz Centre for Infection Research (HZI), Central Facility for Microscopy, \\ 38124 Braunschweig, Germany; Mathias.Muesken@helmholtz-hzi.de \\ 5 Institute for Chemistry and Biology of the Marine Environment, University Oldenburg, \\ 26129 Oldenburg, Germany; peter.schupp@uni-oldenburg.de \\ * Correspondence: Joachim.Wink@helmholtz-hzi.de
}

\section{check for} updates

Citation: Pira, H.; Risdian, C.; Kämpfer, P.; Müsken, M.; Schupp, P.J.; Wink, J. Zooshikella harenae sp. nov., Isolated from Pacific Oyster

Crassostrea gigas, and Establishment of Zooshikella ganghwensis subsp. marina subsp. nov. and Zooshikella ganghwensis subsp. ganghwensis subsp nov. Diversity 2021, 13, 641. https:// doi.org/10.3390/d13120641

Academic Editor: Ipek Kurtboke

Received: 15 November 2021

Accepted: 1 December 2021

Published: 3 December 2021

Publisher's Note: MDPI stays neutral with regard to jurisdictional claims in published maps and institutional affiliations.

Copyright: (c) 2021 by the authors. Licensee MDPI, Basel, Switzerland. This article is an open access article distributed under the terms and conditions of the Creative Commons Attribution (CC BY) license (https:// creativecommons.org/licenses/by/ $4.0 /)$.
Abstract: Here, we describe the polyphasic taxonomy of a novel isolated strain $\mathrm{WH} 53^{\mathrm{T}}$ from the genus Zooshikella isolated from the sand sediment located between the lumen of the Crassostrea gigas From Germany. Phylogenetic analysis determined that the strain $\mathrm{WH}_{53}{ }^{\mathrm{T}}$ had a high similarity to Zooshikella ganghwensis JC2044 ${ }^{\mathrm{T}}$ (99.57\%) and Zooshikella marina LMG $28823^{\mathrm{T}}(99.36 \%)$. Strain $\mathrm{WH} 53^{\mathrm{T}}$ contained ubiquinone-9 (Q-9) as the predominant menaquinone, and the major fatty acids were $C_{16: 0}, C_{16: 1} \omega 7 c$, and $\mathrm{C}_{18: 1} \omega 7 \mathrm{c}$. Diphosphatidylglycerol, phosphatidylglycerol, phosphatidylethanolamine, amino phospholipids, and unidentified phospholipids were identified as their polar lipid composition. The DNA G+C content and genome size of strain $\mathrm{WH} 53^{\mathrm{T}}$ were $40.08 \mathrm{~mol} \%$ and 5,914,969 bp, respectively. Digital DNA-DNA hybridisation (dDDH) for strain $\mathrm{WH} 53^{\mathrm{T}}$ against Z. ganghwensis JC2044 ${ }^{\mathrm{T}}$ and $\mathrm{Z}$. marina LMG $28823^{\mathrm{T}}$ showed low relatedness values of $26.3 \%$ and $26.1 \%$, respectively. The extract of strain $\mathrm{WH} 53^{\mathrm{T}}$ exhibited antimicrobial property. Strain $\mathrm{WH} 53^{\mathrm{T}}$ represents a novel species in the genus Zooshikella. We propose the name of Zooshikella harenae sp. nov., with the type strain WH53 $\left(=\mathrm{DSM} 111628^{\mathrm{T}}=\mathrm{NCCB} 100808^{\mathrm{T}}\right)$. Furthermore, the dDDH, average nucleotide identity (ANI), percentage of conserved proteins (POCP), and amino acid identity (AAI) value between $\mathrm{Z}$. marina LGM $28823^{\mathrm{T}}$ and Z. ganghwensis DSM $15267^{\mathrm{T}}$ were $79.9 \%, 97.84 \%, 76.08 \%$, and $87.01 \%$, respectively, suggesting that both of them should be reclassified as Z. ganghwensis subsp. marina subsp. nov. and Z. ganghwensis subsp. ganghwensis DSM 15267 subsp. nov.

Keywords: pacific oyster Crassostrea gigas; polyphasic taxonomy; Wilhelmshaven Sea; Zooshikella

\section{Introduction}

A critical reduction in discovering new antimicrobial compounds has driven us to search for rare antibiotic-producing species from underexplored habitats like the sea [1]. Microbiologists, pharmacologists, and biochemists have developed an interest in the marine environment in order to harvest water-soluble bacterial pigments. With the recent growth in awareness of the advantages of natural versus synthetic goods, the worldwide market for bio-pigments is projected to grow [2]. The analysis of a potential natural ecosystem is the first and most significant stage in locating an environment that may accommodate a wide range of bio-pigment sources. The marine environment is home to over $80 \%$ of 
all living organisms [3]. It is a rich source of aquatic microbial organisms with a wider variety than their telluric equivalents [4]. The marine environment is now being touted as a promising source of bio-pigment [5]. Many microorganisms from such biotopes have previously been studied for pigment synthesis. At the same time, a large number of them are used for different industrial applications [4]. The capacity of marine microbes to create colors in harsh settings, such as very acidic/alkaline environments ( $\mathrm{pH} 4$ and $>9$ ), extreme temperatures (2-15 C and $60-110{ }^{\circ} \mathrm{C}$ ), and restricted substrate supply, determines their choice [6,7]. In this study, we report the polyphasic taxonomy of a novel isolate from the genus Zooshikella from the sand sediment located between the lumen of the Crassostrea gigas. The genus Zooshikella belongs to Gram-negative bacteria, which are characterised as aerobic, chemo-organotrophic, and halophilic bacteria in the family Zooshikellaceae (which previously was in the family Hahellaceae) [8,9]. Prodigiosin and cycloprodigiosin are two members of secondary metabolites for Zooshikella sp. [9-11]. Many bacteria, including Serratia marcescens, Hahella chejuensis, Streptomyces variegatus, Colwellia (Vibrio) psychrerythraea, Pseudomonas magnesiorubera, and other eubacteria, produce prodigiosin (PDG) [12]. Prodigiosin belongs to the prodiginine community, which is made up of structural isomers with a tripyrrole center and various alkyl chains. This compound has significant biological potential because of its antimicrobial [13], antimalarial [14], anticancer [15], and immunosuppressive properties [16]. According to a recent study, prodigiosin or its analogues were recently found to be successful biological control agents against harmful algae $[17,18]$. They could also be used as a natural dye [19] and are classified as cell growth regulators [20]. On the other hand, cycloprodigiosin ( $\mathrm{cPDG}$ ) is only produced in trace amounts by a few marine bacteria, such as Pseudoalteromonas (Alteromonas) rubra, Pseudoalteromonas denitrificans, and Vibrio gazogenes [21-23]. Cycloprodigiosin hydrochloride has demonstrated potent anticancer activity against various cancer cell lines, implying that CPDG may belong to a new anticancer drug class [12,24-26]. At the moment of writing, the family of Zooshikellaceae is comprised of genera Endozoicomonas, Kistimonas, Parendozoicomonas, and Zooshikella. Zooshikella includes only two species with validly published names as Zooshikella ganghwensis and Zooshikella marina [9,11]. Zooshikella rubidus S1-1 has been effectively published [10], but its species name remains to obtain approval.

\section{Materials and Methods}

\subsection{Isolation}

Oysters were collected in December 2019 from the Wilhelmshaven Sea, located in the north of Germany (latitude: 53.5131; longitude: 08.14714). The strain $\mathrm{WH} 53^{\mathrm{T}}$ was isolated from the sand sediment located between the lumen of pacific oyster Crassostrea gigas with the dilution plate technique on the artificial seawater medium (ASW/1000 mL, agar $15.0 \mathrm{~g}$, $\mathrm{pH}$ 7.3) from ATI Coral Ocean salt given $3.9 \%(w / v)$ for 12 days at $30{ }^{\circ} \mathrm{C}$ meanwhile, ASW was enriched with $2 \mathrm{mg} / \mathrm{L}$ biotin (Vitamin B7), $20 \mathrm{mg} / \mathrm{L}$ nicotinic acid, $10 \mathrm{mg} / \mathrm{L}$ thiamine (Vitamin B1), $10 \mathrm{mg} / \mathrm{L}$ 4-Aminobenzoic acid, $5 \mathrm{mg} / \mathrm{L}$ pantothenic acid, $50 \mathrm{mg} / \mathrm{L}$ pyridoxamine (Vitamin B6), $20 \mathrm{mg} / \mathrm{L}$ cyanocobalamin (Vitamin B12). To avoiding fungal contamination, $50 \mathrm{mg} / \mathrm{mL}$ cycloheximide was used. The unique pinkish-red colonies with a metallic sheen were picked up and transferred to the marine agar medium (MA) and were purified by sequential streaking on the same medium.

\subsection{Morphological, Physiological, and Biochemical Studies}

Morphological observation, including motility via light microscopy (Zeiss Axio Sc pie. A1 microscope), was conducted with cells growing on MB medium for 3 days at $30{ }^{\circ} \mathrm{C}$. For electron microscopy, cells growing for 2 days at $30{ }^{\circ} \mathrm{C}$ in $\mathrm{MB}$ (marine broth) medium were fixed with aldehydes (final concentrations: $5 \%$ formaldehyde and $2 \%$ glutaraldehyde), dehydrated in a gradient series of acetone, critical point dried, and coated with gold-palladium, as previously described [27]. Images were acquired with a Zeiss Merlin field emission scanning electron microscope (FESEM) at various magnifications and a $25: 75 \%$ ratio of Everhart-Thornley SE-detector and Inlens-SEM detector. Growth at 
different temperatures $\left(4,15,20,25,30,35,40\right.$, and $\left.45^{\circ} \mathrm{C}\right)$ and $\mathrm{pH}$ range $(\mathrm{pH} 5,6,7,8,9,10$, and 11) were evaluated on MA medium. Sodium chloride tolerance was tested using different concentration of $\mathrm{NaCl}(w / v): 0 \%, 2.5 \%, 5.0 \%, 7.5 \%, 10 \%, 15 \%, 25 \%, 30 \%$ based on the method of Kutzner [28]. A carbohydrate utilisation study was carried out on ISP9 medium supplemented with $1 \%$ carbon sources [29] and $2.5 \% \mathrm{NaCl}$. Incubation on all media was conducted for 9 days at $30^{\circ} \mathrm{C}$. The biochemical study was conducted by using ApiZym [30] and Api Coryne [31] stripes. Antibiotic susceptibility was tested on MA medium for $48 \mathrm{~h}$ containing different antibiotics: polymyxin $(50 \mu \mathrm{g} / \mathrm{mL})$, gentamycin $(50 \mu \mathrm{g} / \mathrm{mL})$, oxytetracycline $(10 \mu \mathrm{g} / \mathrm{mL})$, ampicillin $(100 \mu \mathrm{g} / \mathrm{mL})$, chloramphenicol $(30 \mu \mathrm{g} / \mathrm{mL})$, spectinomycin $(50 \mu \mathrm{g} / \mathrm{mL})$, kanamycin $(50 \mu \mathrm{g} / \mathrm{mL})$, cephalosporin $(50 \mu \mathrm{g} / \mathrm{mL})$, fusidic acid $(50 \mu \mathrm{g} / \mathrm{mL})$, bacitracin $(50 \mu \mathrm{g} / \mathrm{mL})$, thiostrepton $(50 \mu \mathrm{g} / \mathrm{mL})$, trimethoprim $(50 \mu \mathrm{g} / \mathrm{mL})$, erythromycin $(15 \mu \mathrm{g} / \mathrm{mL})$, and tetracycline $(50 \mu \mathrm{g} / \mathrm{mL})$.

\section{3. $16 S$ rRNA Gene Analysis}

According to the manufacturer's instructions, genomic DNA was obtained using the Invisorb Spin Plant Mini Kit (stratec molecular, Germany). Primahana et al. [32] identified the amplification and purification of the $16 \mathrm{~S}$ rRNA gene sequence by PCR. Primer F27 (5'AGAGTTTGATCMTGGCTCAG3') and 1492R (5'TACGGYTACCTTGTTACGACTT$\left.3^{\prime}\right)$ [33] were used for 16S rRNA gene sequencing employing a 3730XL automatic sequencer from Applied Biosystems (ABI). The sequence was edited and assembled by BioEdit software (version 7.0.5.3) [34]. An almost-complete 16S rRNA gene sequence (1400 bp) of strain $\mathrm{WH} 53^{\mathrm{T}}$ was obtained and was deposited in GenBank with the accession number MW888978.

Identification of the closest strains of strain $\mathrm{WH} 53^{\mathrm{T}}$ based on $16 \mathrm{~S}$ rRNA gene sequence similarity was determined using the EZBioCloud server (http:/ / www.ezbiocloud.net/) (accessed on 12 October 2020) [35]. Phylogenetic analysis of the 16S rRNA gene was performed by uploading the $16 \mathrm{~S}$ rRNA gene sequences of strain $\mathrm{WH} 53^{\mathrm{T}}$ in the GGDC web server (http:/ /ggdc.dsmz.de/) (accessed on 7 October 2021) [36]. The sequence was analysed using the DSMZ phylogenomics pipeline adapted to single genes [37]. According to Meier-Kolthoff et al. [38], pairwise sequence similarities were determined. MUSCLE was used to do a multiple sequence alignment [39]. Maximum likelihood (ML) and Maximum parsimony (MP) trees were inferred by using Randomised Axelerated Maximum Likelihood (RAxML) [40] and TNT (Tree analysis using New Technology) program [41], respectively. Rapid bootstrapping with the autoMRE (extended majority rule) bootstrapping criterion [42] was employed for ML analysis. As for MP, bootstrapping replicates (1000) were used combined with tree-bisection-and-reconnection branch swapping and ten random sequence addition replicates. The sequences were evaluated using the $\mathrm{X}^{2}$ tests employed in PAUP* (Phylogenetic Analysis using Parsimony*) [43].

\subsection{Chemotaxonomy}

The biomass for the chemical analyses was produced and collected for 7 days at $30^{\circ} \mathrm{C}$ in a $250 \mathrm{~mL}$ flask containing $100 \mathrm{~mL}$ of MB medium on a rotary shaker (160 revolutions per minute). The freeze-dried biomass was used for the chemotaxonomic study. Minnikin's method [44] for extracting isoprenoid quinones was used and was analysed by high-performance liquid chromatography equipped with diode-array detection and mass spectrometry (HPLC-DAD-MS), as described by Risdian et al. [45] with some modification of the column, mobile phase, and flow rate. Solvent A (35\% isopropanol $+1 \%$ water $+0.1 \%$ formic acid) and solvent B (65\% acetonitrile $+0.1 \%$ formic acid) were used for isocratic condition with $0.3 \mathrm{~mL} / \mathrm{min}$. A Waters ACQUITY UPLC BEH C18 column $(2.1 \times 50 \mathrm{~mm}$, $1.7 \mu \mathrm{m})$ was used to separate the isoprenoid quinones. Extraction and methylation of fatty acids were done according to Sasser [46]. The analysis of fatty acid methyl esters (FAME) was conducted using Agilent 6890N gas chromatography equipped with FID (flame ionisation detector). A Macherey Nagel Optima 5 column was used to isolate the methyl esters of fatty acids (5\% phenyl, 95\% dimethylpolysiloxane; $50 \mathrm{~m}$ length; $0.32 \mathrm{~mm}$ 
inner diameter; $0.25 \mu \mathrm{m}$ film thickness). The retention times of individual fatty acid methyl esters were compared to standards to identify them (in-house reference standard).

\subsection{Whole-Genome Analysis}

Illumina's next-generation sequencing technology with MiSeq 600 cycle v3 was used for whole-genome sequencing, and Unicycler was used for genome de novo assembly [47]. Evaluation of $16 \mathrm{~S}$ rRNA gene purity of strain $\mathrm{WH} 53^{\mathrm{T}}$ in its genome assembly was performed using the ContEst16S algorithm (https: / / www.ezbiocloud.net/tools/contest16s) (accessed on 12 March 2021) [48]. Automated genome annotation was carried out using the NCBI Prokaryotic Genome Annotation Pipeline PGAP [49]. The draft genome assembly was also submitted to the RAST (Rapid Annotation using Subsystem Technology) database (https: / / rast.nmpdr.org/) (accessed on 28 April 2021) for metabolic reconstruction analysis [50]. Prediction of secondary metabolite gene clusters was conducted using antiSMASH server (https: / / antismash.secondarymetabolites.org /) (accessed on 13 March 2021) [51,52]. The phylogenomic tree was created based on the whole-genome sequence of strain WH53 and its closest phylogenetic neighbors using the Type (Strain) Genome Server (TYGS) (https://tygs.dsmz.de/) [53]. The genome sequence data of strain $\mathrm{WH} 53^{\mathrm{T}}$ were uploaded to the Type (Strain) Genome Server (TYGS) (https: / / tygs.dsmz.de) (accessed on 3 November 2021). The analysis also made use of recently introduced methodological updates and features [54]. The TYGS provided the results on 2021-11-02. All pairwise comparisons for phylogenomic inference were performed using Genome BLAST Distance Phylogeny (GBDP), and accurate intergenomic distances were calculated using the 'trimming' algorithm and distance formula d5 [36]. One hundred distance replicates were calculated each. A second GBDP phylogenomic analysis for generating a better resolved phylogeny was inferred using the amino acid sequences of the entire proteome [30]. The Genome-to-Genome Distance Calculator (GGDC 2.1) was used to calculate digital DDH (dDDH) values and confidence intervals using the suggested settings (GGDC 2.1) [36]. A balanced minimum evolution tree was inferred from the resulting intergenomic distances with branch support via FASTME 2.1.6.1, including Subtree Pruning and Regrafting (SPR) postprocessing [55]. The branch support of the tree was determined from 100 pseudobootstrap replicates each. Additionally, the KBase database was subjected to further genome-based phylogenetic analysis using the Insert Genome Into Species Tree v2.2.0 tool [56]. [56] Prokka v1.14.5 was used to annotate the assembled genome first [57]. The process was then repeated by choosing a subset of 40 public KBase genomes that were closely related to the strain genome. Alignment similarity to a subset of 49 COG (Clusters of Orthologous Groups) domains of core universal genes was used to assess relatedness. The strain genome was put into a curated multiple sequence alignment (MSA) for each COG family, concatenated, and a phylogenetic tree was built by FastTree2 using maximum-likelihood [58].

OrthoANIu algorithm [59] (https: / / www.ezbiocloud.net/tools/ani) (accessed on 5 May 2021) was used for the determination of average nucleotide identity (ANI), genome size, and guanine and cytosine $(\mathrm{G}+\mathrm{C})$ content. To assay genome relatedness between the strain $\mathrm{WH}_{53}{ }^{\mathrm{T}}$, the genus of Zooshikella (Z. marina LGM $28823^{\mathrm{T}}$ and Z. ganghwensis DSM $\left.15267^{\mathrm{T}}\right)$, and the alone genus of Mangrovitalea $\left(M\right.$. sediminis MCCC $1 \mathrm{~K} 03312^{\mathrm{T}}=$ JCM $32104^{\mathrm{T}}$ ), besides ANI and $\mathrm{dDDH}$, the average amino acid identity (AAI) value (http: / / enve-omics.ce.gatech.edu/aai/index) (accessed on 5 September 2021)and the percentage of conserved proteins (POCP) value (https://github.com/2015qyliang/POCP) (accessed on 9 September 2021) for analysis and interpretation of the phylogenomics pipeline from DSMZ were calculated [60]. If the POCP values are less than 50\%, the species are classified into different genus, and more than $50 \%$ are in the same genus [60]. AAI less than $60 \%$ are in different genus, and more than $60 \%$ are in the same genus [61]. For this purpose, amino acid sequences from POCP for AAI were used. Draft genome of strain WH53 and Zooshikella marina LMG $28823^{\mathrm{T}}$ were deposited at DDBJ/EMBL/GenBank under the accession number JAGSOY000000000 and JAGSGA000000000, respectively. 


\subsection{DNA-DNA Hybridisation ( $D D H$ )}

DNA-DNA hybridisation was performed following the procedure of Ziemke et al. [62], except that for nick translation, $2 \mu \mathrm{g}$ DNA was labeled during $3 \mathrm{~h}$ of incubation at $15{ }^{\circ} \mathrm{C}$. This method was performed for the DNA of strain $\mathrm{WH} 53^{\mathrm{T}}$ and its closest relatives, Zooshikella ganghwensis DSM $15267^{\mathrm{T}}$ and Zooshikella marina LGM $28823^{\mathrm{T}}$.

\subsection{Secondary Metabolite Production and Antimicrobial Activity}

The strain $\mathrm{WH} 53^{\mathrm{T}}$ was grown in $250 \mathrm{~mL}$ Erlenmeyer flasks containing $100 \mathrm{~mL} \mathrm{MB}$ medium containing $2 \%(v / w)$ XAD-2 polymeric resin for 5 days at $30{ }^{\circ} \mathrm{C}$ on a shaker (160 revolutions per minute). Separation of XAD-2 was conducted by filtration, and acetone was used to extract secondary metabolites from XAD-2. The extract was dried by a rotary evaporator $\left(40^{\circ} \mathrm{C}\right)$. The dried extract was dissolved with $1 \mathrm{~mL}$ methanol, which resulted in the initial value of concentration of $100 \%$. The extract was tested against some microbes: Escherichia coli wild type BW25113, Escherichia coli acrB JW25113, Pseudomonas aeruginosa DSM 19882, Staphylococcus aureus Newman, Citrobacter freundii DSM 30039, Acinetobacter baumannii DSM 30008, Bacillus subtilis DSM 10, Mycobacterium smegmatis ATCC 700084, Mucor hiemalis DSM 2656, Wickerhamomyces anomalus DSM 6766, and Candida albicans DSM 1665. The MIC (minimal inhibitory concentration) values were determined in 96-well microplates by incubating the bacterial test strain and the extract in Mueller-Hinton (MH) broth (Merck, Darmstadt, Germany) and Middelbrock broth medium (for M. smegmatis ATCC 700084; Becton, Dickinson and Company, Le Pont-de-Claix, France) with starting OD600 $=0.01$. For the fungal test strain, the initial OD600 $=0.05$ and Mycosel broth (Myc; Carl Roth GmbH + Co. KG, Karlsruhe, Germany; $1 \%$ phytone peptone, $1 \%$ glucose, $50 \mathrm{mM}$ HEPES) was used for the evaluation. The lowest concentration of the tested extract that inhibited the observable growth of test microorganisms was defined as the MIC value. Twofold serial dilutions were used to determine the antimicrobial activity of the extract (6.67-0.05\%) [63].

\section{Result and Discussion}

\subsection{Morphological, Physiological, and Biochemical Results}

Strain $\mathrm{WH}_{5} 3^{\mathrm{T}}$ was a motile, spirillum form; cell size measurement demonstrated a diameter of $0.6-0.7 \mu \mathrm{m}$ in width and 4.1-13.5 $\mu \mathrm{m}$ in length (Figure 1) and no-spore-form. The optimal growth temperature was observed at $30{ }^{\circ} \mathrm{C}$, and the $\mathrm{pH}$ optimum was revealed at $\mathrm{pH} 7$. Growth was not detected on the medium without $\mathrm{NaCl}$. Sodium chloride tolerance was up to $7.5 \%$, with the optimum growth on media containing $2.5 \% \mathrm{NaCl}$. Study on biochemical property-based API ZYM test suggested that strain $\mathrm{WH} 53^{\mathrm{T}}$ had the strong activity of phosphatase alkaline and leucine arylamidase, but no activity for chymotrypsin and $\beta$-glucuronidase (Table 1 ). The extract of strain $\mathrm{WH}^{2} 3^{\mathrm{T}}$ could strongly inhibit Escherichia coli wild type BW25113, Escherichia coli acrB JW25113, Staphylococcus aureus Newman, Citrobacter freundii DSM30039, Acinetobacter baumannii DSM 30008, Bacillus subtilis DSM 10, Mycobacterium smegmatis ATCC 700084, Mucor hiemalis DSM 2656, Wickerhamomyces anomalus DSM 6766, and Candida albicans DSM 1665. Moderate activity was only found against Pseudomonas aeruginosa DSM 19882 (Table S1). This result suggested that strain $\mathrm{WH} 53^{\mathrm{T}}$ could produce active compounds against various microbes that might benefit oysters to protect themselves from pathogenic microbes. 


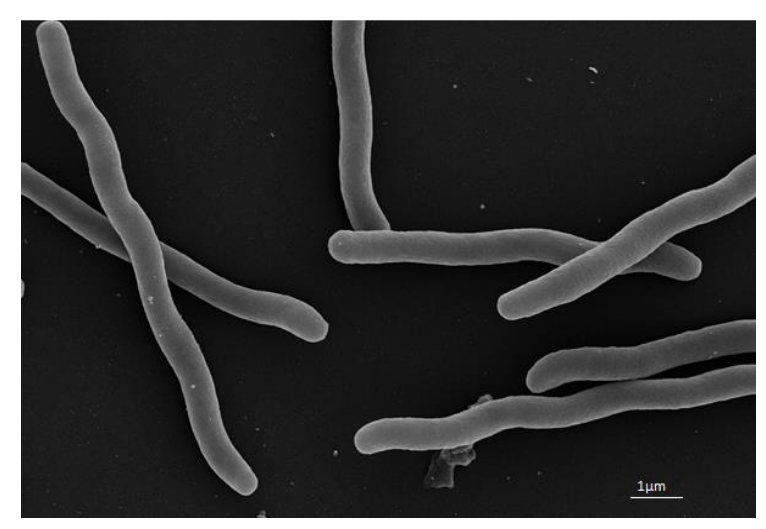

Figure 1. Scanning electron microscopy images of strain $\mathrm{WH} 53^{\mathrm{T}}$.

Table 1. Enzymes produced by strain $\mathrm{WH} 53^{\mathrm{T}}$ detected by ApiZym system.

\begin{tabular}{cccc}
\hline Enzyme & Observation & Enzyme & Observation \\
\hline Phosphatase alkaline & ++ & Naphtol-AS-BI-phosphohydrolase & ++ \\
Esterase (C4) & + & $\alpha$-galactosidase & $(+)$ \\
Esterase lipase (C8) & + & $\beta$-galactosidase & $(+)$ \\
Lipase (C14) & $(+)$ & $\beta$-glucuronidase & - \\
Leucin arylamidase & ++ & $\alpha$-glucosidase & ++ \\
Valine arylamidase & $(+)$ & $\beta$-glucosidase & $(+)$ \\
Cystine arylamidase & $(+)$ & N-acetyl-beta-glucosaminidase & ++ \\
Trypsin & $(+)$ & $\alpha$-mannosidase & + \\
Chymotrypsin & - & $\alpha$-fucosidase & $(+)$ \\
Phosphatase acid & ++ & & \\
\hline++ strong; good; $(+)$ weak; - no activity. & &
\end{tabular}

Strain $\mathrm{WH} 53^{\mathrm{T}}$ was sensitive to polymyxin, gentamycin, chloramphenicol, spectinomycin, kanamycin, erythromycin, and tetracycline. Resistance was detected against oxytetracycline, ampicillin, cephalosporin, fusidic acid, bacitracin, thiostrepton, and trimethoprim.

\section{2. $16 \mathrm{~S}$ rRNA Gene Analysis}

Based on the result from the EZBioCloud server, strain $\mathrm{WH}_{5} 3^{\mathrm{T}}$ had high sequence similarities to Zooshikella ganghwensis JC2044 ${ }^{\mathrm{T}}$ (99.57\%) and Zooshikella marina JC333 ${ }^{\mathrm{T}}$ (99.36\%). Strain $\mathrm{WH} 53^{\mathrm{T}}$ was also closely related to 'Zooshikella rubidus' S1-1 (99.36\%). The results of phylogenetic analyses showed that strain $\mathrm{WH} 53^{\mathrm{T}}$ formed a clade with Z. ganghwensis JC2044 ${ }^{\mathrm{T}}$, Z. marina JC333' ${ }^{\mathrm{T}}$, and 'Z. rubidus' S1-1 supported by bootstrap values of $100 \%$ from ML and MP analyses (Figure 2).

\subsection{Chemotaxonomic Characterization}

Major detected fatty acids of strain $\mathrm{WH}_{53}^{\mathrm{T}}$ were $\mathrm{C}_{16: 0}(39.01 \%), \mathrm{C}_{16: 1} \omega 7 \mathrm{c}(41.12 \%)$, and $\mathrm{C}_{18: 1} \omega 7 \mathrm{c}(11.31 \%)$. Diphosphatidylglycerol (DPG), phosphatidylglycerol (PG), phosphatidylethanolamine (PE), aminophospholipid (APL), and unidentified phospholipids $(\mathrm{PL})$ were the polar lipid identified in strain $\mathrm{WH}^{2} 3^{\mathrm{T}}$ (Supplementary Figure S1). The major quinone of strain $\mathrm{WH}_{5} 3^{\mathrm{T}}$ was ubiquinone-9 (Q-9). 


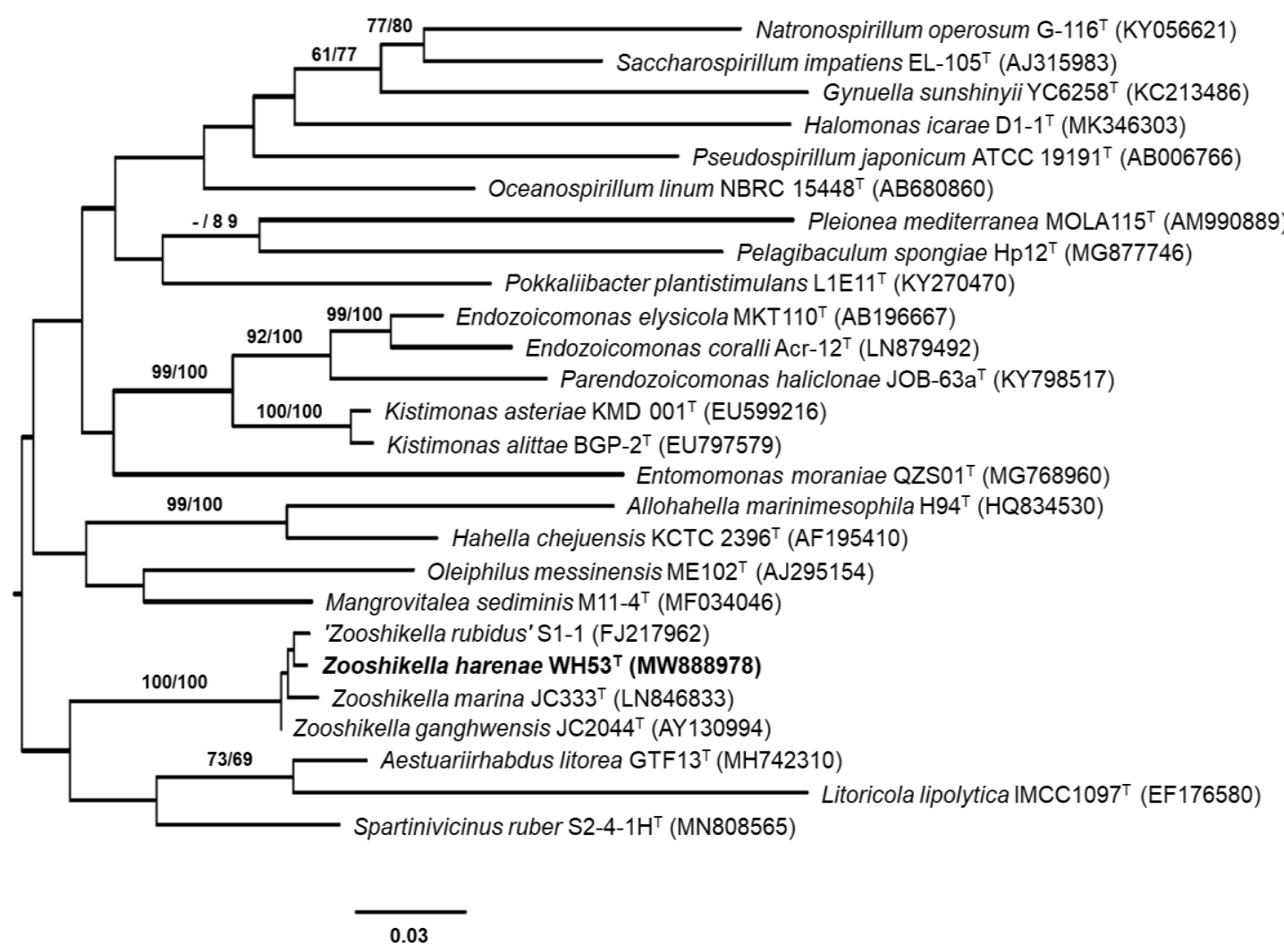

Figure 2. The GTR+GAMMA model was used to infer the ML tree, which was then rooted using midpoint-rooting. The branches were scaled in terms of the expected number of substitutions per site. The numbers above the branches represent the support values obtained from ML (left) and MP (right) bootstrapping. They were meaningful more than $60 \%$. After 1000 replicates, the ML bootstrapping converged, with an average support of 59.57\%. MP analysis yielded the best score of 1942 (consistency index 0.41, retention index 0.44) and two best trees. The MP bootstrapping average support was 64.04\%.

\subsection{Genomic Characteristics and Phylogenomic Analysis}

Only one 16S rRNA gene sequence was detected in the whole-genome sequence of strain $\mathrm{WH}_{5} 3^{\mathrm{T}}$, indicating that the genomic data was not contaminated by other organisms. The draft genome assembly of strain $\mathrm{WH}^{2} 3^{\mathrm{T}}$ consisted of 5,914,969 bp (377 contigs) with a G+C content of $40.08 \mathrm{~mol} \%$ (GenBank accession No. JAGSOY000000000). The phylogenomic tree with the very low average branch support (25.8\%) derived from TYGS using genome sequence showed that strain $\mathrm{WH}^{2} 3^{\mathrm{T}}$, instead of being close to Z. ganghwensis DSM $15267^{\mathrm{T}}$ and Z. marina LMG $28823^{\mathrm{T}}$, was located in a low supported clade with Azomonas agilis DSM $375^{\mathrm{T}}$ (Supplementary Figure S2). On the other hand, the phylogenetic tree based on whole-proteome-based GBDP distances showed a very high average branch support of $94.1 \%$, which is more reliable than the phylogenomic tree result (Figure 3). Based on the proteome tree, strain $\mathrm{WH} 53^{\mathrm{T}}$ was in a very high supported clade together with $\mathrm{Z}$. ganghwensis DSM $15267^{\mathrm{T}}$ and Z. marina LMG $28823^{\mathrm{T}}$. The other phylogenomic tree resulted from the Insert Genome Into Species Tree v2.2.0 tool [56] using 49 COG suggested that strain $\mathrm{WH}_{53}{ }^{\mathrm{T}}$ was in one clade together with other Zooshikella species with very high supporting value (Figure 4). 


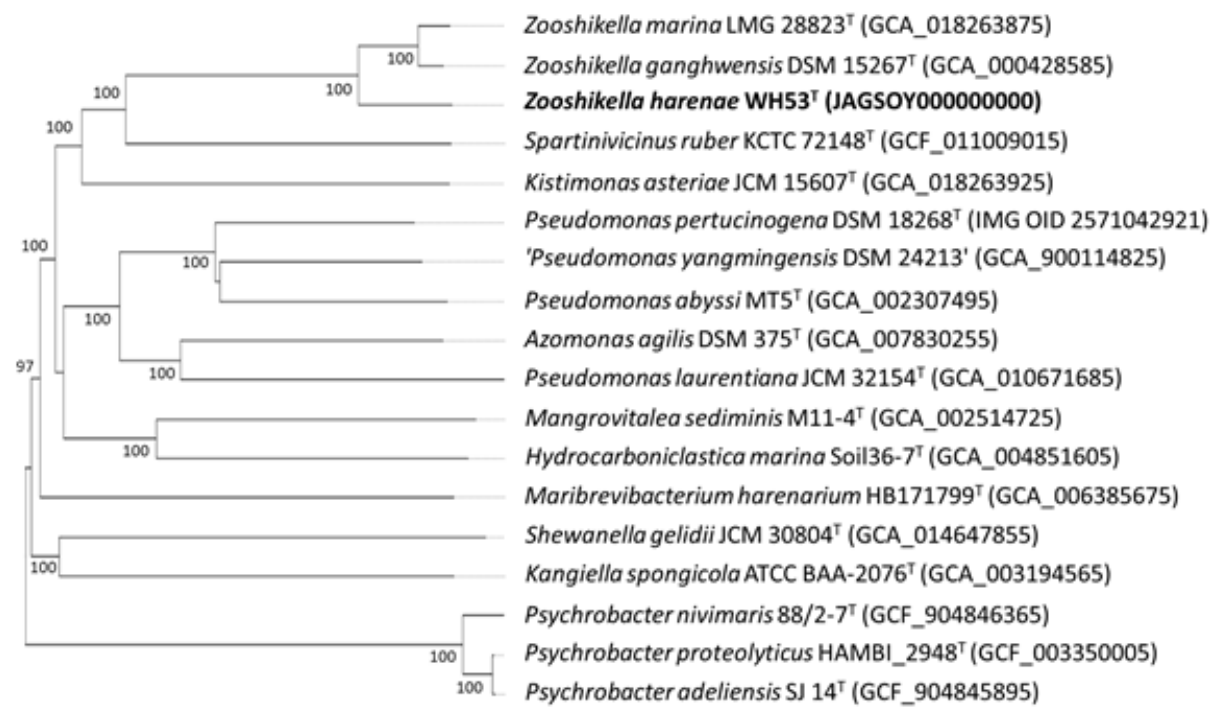

Figure 3. Phylogenomic tree inferred from whole-proteome-based GBDP distances showing relationships between strain $\mathrm{WH} 53^{\mathrm{T}}$ and the closely related type strains based on Type (Strain) Genome Server (TYGS) (https://tygs.dsmz.de/) (accessed on 3 November 2021) [54]. The number at the nodes are GBDP pseudo-bootstrap support values $>60 \%$ from 100 replications, with average branch support of $94.1 \%$.

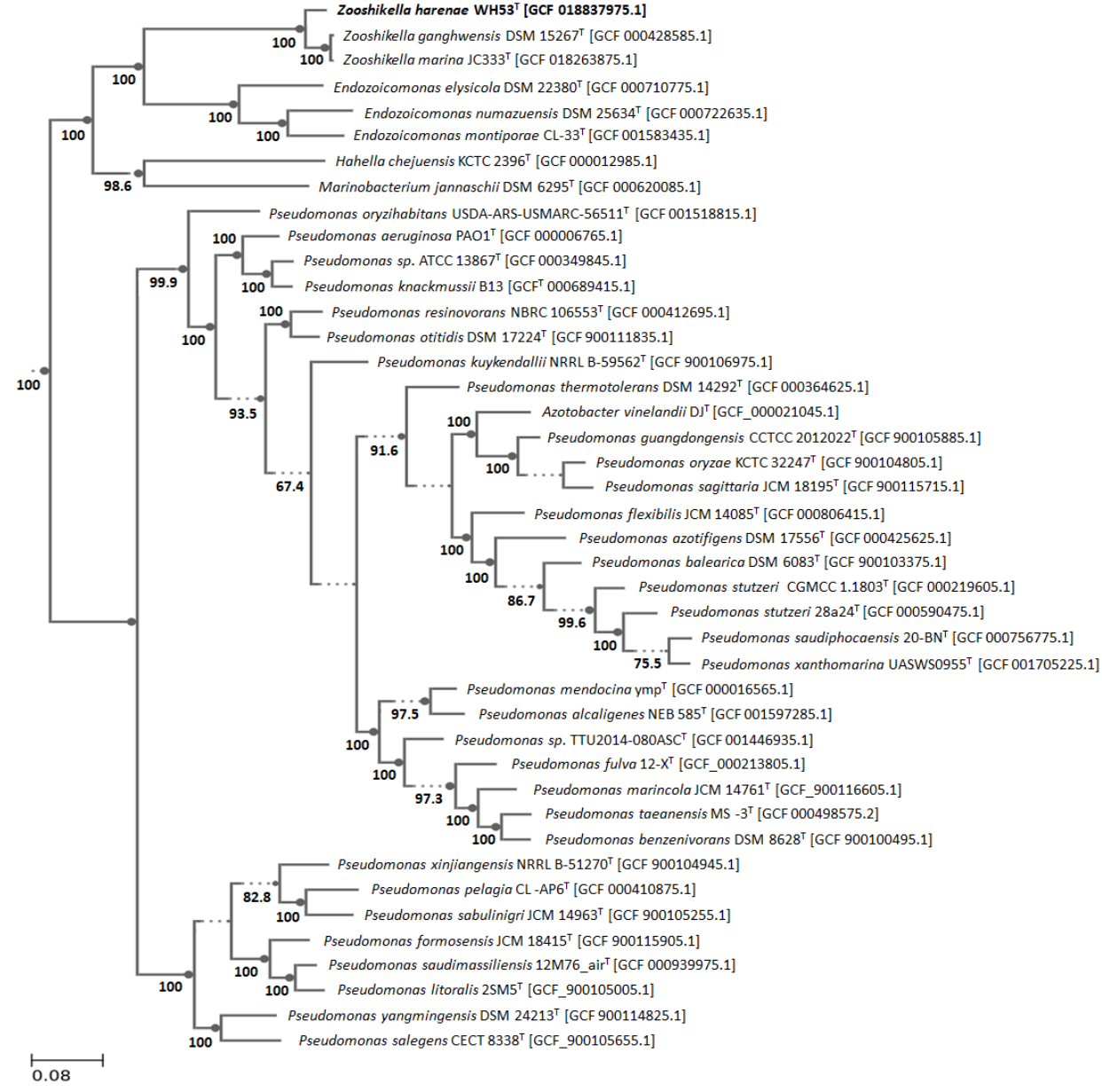

Figure 4. Phylogenomic tree showing relationships between strain $\mathrm{WH} 53^{\mathrm{T}}$ and the closely related type strains based on Insert Genome into Species Tree v2.2.0 tool [56] using 49 COG (Clusters of Orthologous Groups) domains of core universal genes. Bootstrap values $>60 \%$ from 1000 replications are displayed at the nodes. 
As shown in Table 2, all of the compared type strains had ANI values lower than the species cut-off value of $95 \%$, and $\mathrm{dDDH}$ scores were below the $70 \%$ threshold value [64]. The DNA-DNA hybridisation (DDH) analysis of strain $\mathrm{WH}^{2} 3^{\mathrm{T}}$ and its closest relatives revealed a value of $50.1 \%$ against Z. ganghwensis DSM $15267^{\mathrm{T}}$ and $34.6 \%$ against Z.marina LGM $28823^{\mathrm{T}}$, which are also below the $70 \%$ cut-off point for species delineation [65]. However, the dDDH score between Z. marina LGM $28823^{\mathrm{T}}$ and Z. ganghwensis DSM $15267^{\mathrm{T}}$ was more than $70 \%$, indicating that they belong to the same species. Meier-Kolthoff [37] suggested that a value of $79-80 \% \mathrm{dDDH}$ was the threshold for delineating subspecies.

Table 2. ANI and dDDH values of the strain $\mathrm{WH} 53^{\mathrm{T}}$ and its closely related type strains.

\begin{tabular}{|c|c|c|c|c|}
\hline \multirow[t]{2}{*}{ Strain } & \multicolumn{2}{|c|}{$\begin{array}{c}\text { Zooshikella harenae } \\
\text { WH53 }^{\mathrm{T}} \text { (JASOY000000000) }\end{array}$} & \multicolumn{2}{|c|}{$\begin{array}{l}\text { Zooshikella marina } \\
{\text { LMG } 28823^{T}}^{\text {(JAGSGA000000000) }}\end{array}$} \\
\hline & $\begin{array}{c}\text { OrthoANIu } \\
(\%)\end{array}$ & dDDH (\%) & $\begin{array}{l}\text { OrthoANIu } \\
(\%)\end{array}$ & dDDH (\%) \\
\hline $\begin{array}{c}\text { Zooshikella harenae WH53 } \\
\text { (JAGSOY000000000) }\end{array}$ & 100 & 100 & 82.74 & 26.10 \\
\hline $\begin{array}{c}\text { Zooshikella marina LMG } \\
28823^{\mathrm{T}} \text { (JAGSGA000000000) }\end{array}$ & 82.74 & 26.10 & 100 & 100 \\
\hline $\begin{array}{c}\text { Zooshikella ganghwensis } \\
\text { DSM 15267 }\end{array}$ & 82.78 & 26.30 & 97.84 & 79.90 \\
\hline $\begin{array}{c}\text { Endozoicomonas montiporae } \\
\text { CL-33 }^{\mathrm{T}} \text { (CP013251) }\end{array}$ & 66.94 & 24.30 & 66.76 & 28.50 \\
\hline $\begin{array}{c}\text { Endozoicomonas elysicola } \\
\text { (JOJP01000000) }\end{array}$ & 66.93 & 27.50 & 67.44 & 23.30 \\
\hline $\begin{array}{c}\text { Endozoicomonas arenosclerae } \\
\text { (LASA01000000) }\end{array}$ & 66.88 & 23.10 & 67.26 & 22.30 \\
\hline $\begin{array}{l}\text { Endozoicomonas atrinae } \\
\text { (LUKQ02000000) }\end{array}$ & 67.25 & 23.50 & 67.17 & 22.50 \\
\hline $\begin{array}{c}\text { Hahella chejuensis KCTC } \\
2396^{\mathrm{T}}(\mathrm{CP} 000155)\end{array}$ & 66.79 & 38.60 & 66.43 & 29.00 \\
\hline $\begin{array}{l}\text { Marinobacter lutaoensis } \\
\text { (MSCW01000000) }\end{array}$ & 66.03 & 23.20 & 65.40 & 21.50 \\
\hline $\begin{array}{l}\text { Mangrovitalea sediminis } \\
\text { (NTLB01000000) }\end{array}$ & 66.08 & 32.80 & 65.95 & 30.80 \\
\hline $\begin{array}{c}\text { Aestuariirhabdus litorea } \\
\text { (QWEZ01000000) }\end{array}$ & 66.59 & 19.30 & 66.88 & 18.60 \\
\hline $\begin{array}{c}\text { Kistimonas asteriae JCM } \\
15607^{\mathrm{T}} \text { (JAEVHF000000000) }\end{array}$ & 66.84 & 20.00 & 67.08 & 34.40 \\
\hline $\begin{array}{c}\text { Azomonas agilis DSM375 } \\
\text { (NZ_VLKG00000000) }\end{array}$ & 67.62 & 31.80 & 66.35 & 20.40 \\
\hline $\begin{array}{l}\text { Hydrocarboniclastica marina } \\
\text { Soil36-7 }^{\mathrm{T}} \text { (PRJNA479718) }\end{array}$ & 68.07 & 38.60 & 68.17 & 39.50 \\
\hline $\begin{array}{l}\text { Kangiella spongicola ATCC } \\
\text { BAA-2076 }^{\mathrm{T}} \text { (PRJNA473557) }\end{array}$ & 67.74 & 32.90 & 67.63 & 34.10 \\
\hline $\begin{array}{c}\text { Spartinivicinus ruber KCTC } \\
72148^{\mathrm{T}} \text { (PRJNA607118) }\end{array}$ & 68.91 & 21.30 & 69.06 & 22.80 \\
\hline
\end{tabular}

OrthoANIu values $\geq 95 \%$ and dDDH values $>70 \%$ are shaded gray.

Some phenotypic similarities exist between Z. marina LGM $28823^{\mathrm{T}}$ and Z. ganghwensis DSM $15267^{\mathrm{T}}$, such as the same $\mathrm{NaCl}$ tolerance $(5 \%)$ and some enzymatic activities. The genome was predicted to contain a total of 5214 genes, comprising 5180 protein-coding 
genes, 54 tRNA genes, 3 rRNA genes, and 4 non-coding RNA (Table 3). Both types of strains had no activity for myristate lipase, cystine arylamidase, trypsin, naphtol-AS-BIphosphohydrolase, $\alpha$-Glucosidase, $\beta$-Glucosidase, and $\alpha$-fucosidase. Since the dDDH value between these two strains was $79.9 \%$, and they had some similar phenotypic characteristics, therefore, Z. marina LGM $28823^{\mathrm{T}}$ could be reclassified as the subspecies of $Z$. ganghwensis. Moreover, based on the $60 \%$ AAI value [61] and the $50 \%$ POCP value [60] proposed as genus boundaries, strain $\mathrm{WH}^{\mathrm{T}} 3^{\mathrm{T}}$ could be classified within the genus Zooshikella (Table 4).

Table 3. Comparison of phenotypic characteristics that distinguish strain $\mathrm{WH} 53^{\mathrm{T}}$ from the most closely related Zooshikella species. Strains: 1 , WH53 $3^{\mathrm{T}} ; 2$, Zooshikella marina $\mathrm{LMG} 28823^{\mathrm{T}} ; 3$, Zooshikella ganghwensis DSM $15267^{\mathrm{T}} ; 4$, Zooshikella rubidus S1-1 ${ }^{\mathrm{T}}$.

\begin{tabular}{|c|c|c|c|c|}
\hline Characteristic & 1 & 2 & 3 & $4^{+}$ \\
\hline $\mathrm{pH}$ range for growth & $6-8$ & $6-9$ & $5-8$ & $4.5-9.5$ \\
\hline $\mathrm{NaCl}$ tolerance $(w / v)$ & $7.5 \%$ & $5.0 \%$ & $5.0 \%$ & $10 \%$ \\
\hline Color of colony & Red & Red & Red & Dark red \\
\hline Butyrate esterase (C4) & + & $(+)$ & $(+)$ & - \\
\hline Caprylate esterase lipase (C8) & + & $(+)$ & $(+)$ & + \\
\hline Myristate lipase (C14) & $(+)$ & - & - & - \\
\hline Cystine arylamidase & $(+)$ & - & - & - \\
\hline Trypsin & $(+)$ & - & - & - \\
\hline Acid phosphatase & ++ & $(+)$ & + & + \\
\hline $\begin{array}{l}\text { Naphtol-AS-BI- } \\
\text { phosphohydrolase }\end{array}$ & ++ & - & - & - \\
\hline$\alpha$-Glucosidase & + & - & - & - \\
\hline$\beta$-Glucosidase & $(+)$ & - & - & - \\
\hline $\mathrm{N}$-acetyl- $\beta$-glucosaminidase & ++ & ++ & - & - \\
\hline Phosphatase alkaline & ++ & ++ & ++ & + \\
\hline Valine arylamidase & $(+)$ & $(+)$ & $(+)$ & - \\
\hline$\alpha$-galactosidase & $(+)$ & - & - & - \\
\hline$\beta$-galactosidase & $(+)$ & - & - & - \\
\hline$\beta$-glucuronidase & - & - & - & - \\
\hline$\alpha$-mannosidase & + & + & - & - \\
\hline$\alpha$-fucosidase & $(+)$ & - & - & - \\
\hline Glucose fermentation & - & + & - & NR \\
\hline Sucrose fermentation & - & + & - & NR \\
\hline Glycogen fermentation & - & + & - & NR \\
\hline Polar lipids & $\begin{array}{l}\text { DPG-PG- } \\
\text { PE-APL-PL }\end{array}$ & $\begin{array}{l}\text { DPG-PG- } \\
\text { PE-APL-PL }\end{array}$ & $\begin{array}{l}\text { DPG-PG- } \\
\text { PE-AL-PL }\end{array}$ & NR \\
\hline Major fatty acid & $\begin{array}{c}C_{16: 0} \\
C_{16: 1} \omega 7 c \\
C_{18: 1} \omega 7 c\end{array}$ & $\begin{array}{c}\mathrm{C}_{12: 0} 3-\mathrm{OH} \\
\mathrm{C}_{14: 0} \\
\mathrm{C}_{16: 0} \\
\mathrm{C}_{16: 1} \omega 7 \mathrm{c} \\
\mathrm{C}_{18: 1} \omega 7 \mathrm{c}\end{array}$ & $\begin{array}{c}\mathrm{C}_{12: 0} 3-\mathrm{OH} \\
\mathrm{C}_{16: 0} \\
\mathrm{C}_{16: 1} \omega 7 \mathrm{c} \\
\mathrm{C}_{18: 1} \omega 7 \mathrm{c}\end{array}$ & $\begin{array}{c}\mathrm{C}_{12: 0} 3-\mathrm{OH} \\
\mathrm{C}_{16: 0} \\
\mathrm{C}_{18: 1} \omega 7 \mathrm{c}\end{array}$ \\
\hline Major quinone & Ubiquinone-9 & Ubiquinone-9 & Ubiquinone-9 & Ubiquinone-9 \\
\hline Ampicillin susceptibility & - & NR & NR & - \\
\hline Tetracycline susceptibility & + & NR & NR & - \\
\hline Total sequence length (bp) & $5,914,969$ & $6,060,265$ & $5,798,664$ & NR \\
\hline Contigs & 377 & 83 & 414 & NR \\
\hline No. of protein & 5,120 & 5,083 & 4,943 & NR \\
\hline rRNA & 3 & 3 & 10 & NR \\
\hline tRNA & 54 & 55 & 55 & NR \\
\hline No. of Gene & 5241 & 5160 & 5164 & NR \\
\hline Other RNA & 4 & 4 & 4 & NR \\
\hline Pseudogene & 60 & 15 & 152 & NR \\
\hline $\mathrm{G}+\mathrm{C}$ content $(\mathrm{mol} \%)$ & $40.08 \%$ & $40.94 \%$ & $41.02 \%$ & $41 \%$ \\
\hline
\end{tabular}

++ strong; + good; (+) weak; - no activity; NR not reported. ${ }^{\dagger}$ Data from Lee et al. [10]. Diphosphatidylglycerol (DPG), phosphatidylglycerol (PG), phosphatidylethanolamine (PE), aminophospholipid (APL), and unidentified phospholipids (PL). 
Table 4. Genome relatedness between the strain $\mathrm{WH} 53^{\mathrm{T}}$ and the other related type strains according to the average amino acid identity (AAI) value and the percentage of conserved proteins (POCP) value. Strains: 1, Zooshikella ganghwensis

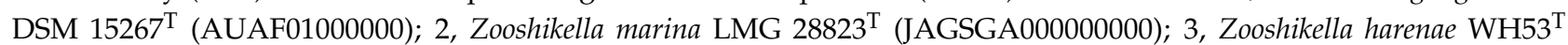
(JAGSOY000000000).

\begin{tabular}{|c|c|c|c|c|c|c|}
\hline \multirow[b]{2}{*}{ Strain } & \multicolumn{2}{|c|}{1} & \multicolumn{2}{|c|}{2} & \multicolumn{2}{|c|}{3} \\
\hline & $\begin{array}{l}\text { POCP } \\
(\%)\end{array}$ & $\begin{array}{l}\text { AAI } \\
(\%)\end{array}$ & $\begin{array}{l}\text { POCP } \\
(\%)\end{array}$ & $\begin{array}{l}\text { AAI } \\
(\%)\end{array}$ & $\begin{array}{l}\text { POCP } \\
(\%)\end{array}$ & $\begin{array}{c}\text { AAI } \\
(\%)\end{array}$ \\
\hline Zooshikella harenae WH53 ${ }^{\mathrm{T}}$ (JAGSOY000000000) & 76.08 & 87.01 & 77.37 & 86.73 & 100 & 100 \\
\hline Zooshikella marina LMG $28823^{\mathrm{T}}$ (JAGSGA000000000) & 76.08 & 87.01 & 100 & 100 & 77.37 & 86.73 \\
\hline 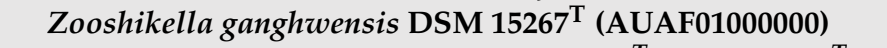 & 100 & 100 & 76.08 & 87.01 & 76.08 & 87.01 \\
\hline $\begin{array}{c}\text { Mangrovitalea sediminis }\left(=\text { MCCC } 1 K 03312^{T}=J C M 32104^{T}\right) \\
(\text { NTLB01000000) }\end{array}$ & 29.76 & 49.90 & 30.51 & 49.76 & 31.26 & 49.79 \\
\hline Endozoicomonas acroporae strain Acr-14 ${ }^{\mathrm{T}}$ (PRJNA422318) & 28.44 & 51.65 & 28.40 & 51.37 & 28.58 & 51.20 \\
\hline Endozoicomonas arenosclerae (PRJNA279233) & 29.50 & 50.97 & 29.08 & 50.74 & 29.40 & 50.58 \\
\hline Endozoicomonas ascidiicola (NZ_LUTW00000000) & 30.17 & 51.00 & 30.26 & 51.06 & 29.82 & 51.32 \\
\hline Endozoicomonas atrinae (NZ_LUKQ00000000) & 26.35 & 50.80 & 26.53 & 50.72 & 26.32 & 50.72 \\
\hline Endozoicomonas elysicola (NZ_JOJP00000000) & 30.89 & 51.22 & 31.17 & 51.11 & 31.27 & 51.19 \\
\hline $\begin{array}{c}\text { Endozoicomonas montiporae Strain LMG } 24815^{\mathrm{T}} \\
\text { (NZ_JOKG00000000) }\end{array}$ & 30.03 & 51.25 & 30.26 & 51.24 & 29.86 & 51.37 \\
\hline Endozoicomonas numazuensis (NZ_JOKH00000000) & 29.82 & 51.41 & 29.94 & 51.11 & 30.08 & 51.02 \\
\hline Hahella chejuensis KCTC 2396 ${ }^{\mathrm{T}}$ (PRJNA16064) & 30.68 & 49.72 & 31.48 & 49.62 & 31.44 & 49.73 \\
\hline Hahella ganghwensis DSM $17046^{\mathrm{T}}$ (NZ_AQXX00000000) & 30.01 & 49.56 & 30.54 & 49.41 & 30.67 & 49.17 \\
\hline Kistimonas asteriae (NZ_JAEVHF000000000) & 33.61 & 53.09 & 33.94 & 52.56 & 34.09 & 52.75 \\
\hline Parendozoicomonas haliclonae (NZ_FWPT00000000) & 31.66 & 51.49 & 32.19 & 51.20 & 32.17 & 50.91 \\
\hline Pseudomonas xiamenensis (NZ_JACLGO000000000) & 30.30 & 51.18 & 30.28 & 51.06 & 30.28 & 50.89 \\
\hline Kistimonas asteriae JCM $15607^{\mathrm{T}}$ (JAEVHF000000000) & 33.61 & 53.09 & 33.92 & 52.55 & 34.09 & 52.75 \\
\hline Spartinivicinus ruber KCTC $72148^{\mathrm{T}}$ (PRJNA607118) & 49.90 & 58.67 & 49.94 & 58.38 & 49.97 & 58.69 \\
\hline Pseudomonas pertucinogena JCM $11590^{\mathrm{T}}$ (BMNN00000000) & 32.11 & 52.18 & 32.53 & 52.10 & 32.18 & 51.93 \\
\hline Pseudomonas yangmingesis DSM $24213^{\mathrm{T}}$ (NZ_FOUI00000000) & 31.78 & 52.27 & 32.05 & 52.20 & 31.74 & 51.95 \\
\hline Pseudomonas abyssi Strain MT5 $^{\mathrm{T}}$ (PRJNA406957) & 31.34 & 51.28 & 32.07 & 51.16 & 31.90 & 50.99 \\
\hline Azomonasa gilis DSM $375^{\mathrm{T}}$ (NZ_VLKG00000000) & 27.95 & 50.87 & 28.25 & 51.03 & 28.53 & 50.95 \\
\hline Hydrocarboniclastica marina Soil36-7 ${ }^{\mathrm{T}}$ (PRJNA479718) & 28.46 & 49.31 & 28.65 & 49.18 & 28.97 & 49.10 \\
\hline Kangiella spongicola ATCC BAA-2076 ${ }^{\mathrm{T}}$ (PRJNA473557) & 25.06 & 47.38 & 25.60 & 47.41 & 24.74 & 47.11 \\
\hline
\end{tabular}

POCP less than $50 \%$ is a different genus, and more than $50 \%$ is the same genus AAI less than $60 \%$ is a different genus, and more than $60 \%$ is the same genus.

It also revealed that $22 \%$ of the genes were assigned to subsystems (Figure 5). Amino acid and derivatives metabolism had the largest feature counts (307), followed by protein metabolism (223) and carbohydrates metabolism (191). Genes responsible for motility and chemotaxis (100), metabolism of aromatic compounds (14), and stress response (76) were also detected. However, only two genes were observed for dormancy and sporulation. The antiSMASH server predicted 18 clusters of genes involved in secondary metabolite biosynthesis, with three clusters demonstrating higher than $60 \%$ similarity to known biosynthetic gene clusters: althiomycin biosynthetic gene cluster $(62 \%)$, indigoidine biosynthetic gene cluster $(80 \%)$, and ectoine biosynthetic gene cluster $(83 \%)$.

Besides the result of genotypic studies such as $16 \mathrm{~S}$ rRNA gene analysis, ANI, dDDH, and $\mathrm{DDH}$, strain $\mathrm{WH} 53^{\mathrm{T}}$ could also be delineated from its closely related type strains by several phenotypic characteristics (Table 3). Myristate lipase, cystine arylamidase, and trypsin were detected in strain $\mathrm{WH}_{53}{ }^{\mathrm{T}}$, while the other Zooshikella type strains had no activity for them. Sodium chloride tolerance of strain $\mathrm{WH} 53^{\mathrm{T}}$ was higher than the other Zooshikella type strains. 

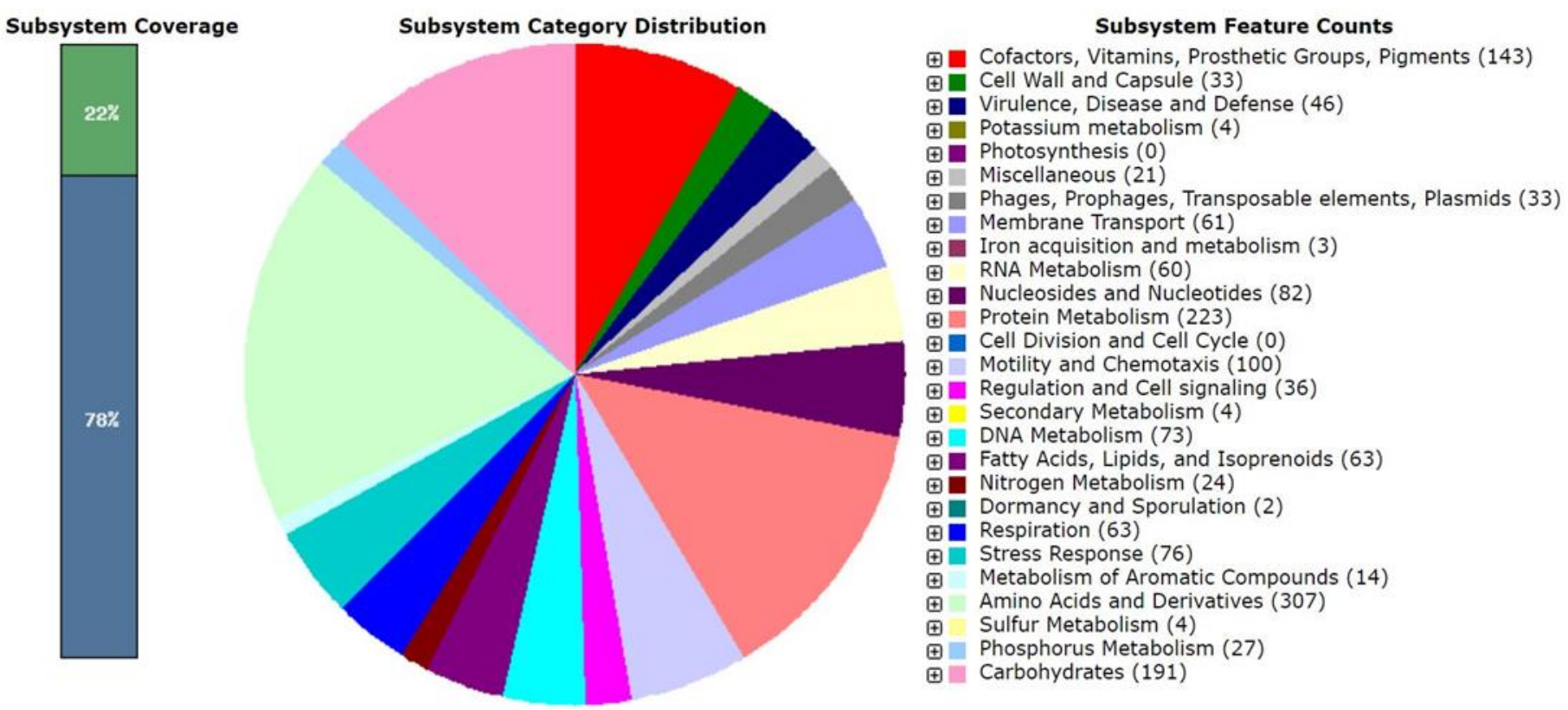

Figure 5. Subsystem category distribution of strain $\mathrm{WH}^{\mathrm{T}} 3^{\mathrm{T}}$ based on RAST annotation server (https:/ / rast.nmpdr.org/) (accessed on 28 April 2021).

\section{Conclusions}

Based on comparing all phenotypic and genotypic traits, strain $\mathrm{WH} 53^{\mathrm{T}}$ belongs to genus Zooshikella and can be separated from the other Zooshikella species as a novel species in the genus Zooshikella, for which the name Zooshikella harenae sp. nov. is proposed.

\section{Description of Zooshikella harenae sp.nov.}

Zooshikella harenae (ha.re'nae. L. gen. n. harenae of sand, referring to the isolation of the strain from the sand trapped in the pacific oyster Crassostrea gigas): Optimal growth is observed at $30^{\circ} \mathrm{C}, \mathrm{pH} 7$ and $2.5 \%(w / v) \mathrm{NaCl}$. Sodium chloride is required for growth. Grows on MA as circular, convex, entire, glistening, opaque, and viscid colonies are pinkish-red colonies with a metallic sheen and approximately $0.5 \mathrm{~mm}$ in diameter. Cells are Gram-stain-negative, motile, spirillum form with aerobic and non-spore-forming. Large amounts of red pigment with a metallic green sheen are produced on an agar medium. Strong activity in acid phosphatase, alkaline phosphatase, leucine arylamidase, naphtholAS-BI-phosphohydrolase, $\alpha$-glucosidase, N-acetyl-beta-glucoseamidase. Good activity for esterase (C4), esterase lipase (C8), $\alpha$-mannosidase. Weak activity for lipase (C14), valine arylamidase, cystine arylamidase, trypsin, $\alpha$-galactosidase, $\beta$-galactosidase, $\beta$-glucosidase, $\alpha$-fucosidase, and no activity for $\beta$-Glucoronidase and chymotrypsin. Glucose, mannose, fructose are used as sole carbon sources, but not arabinose, sucrose, xylose, inositol, rhamnose, raffinose, and cellulose. Major fatty acids are $C_{16: 0}(39.01 \%), C_{16: 1} \omega 7 \mathrm{c}(41.12 \%)$, and $\mathrm{C}_{18: 1} \omega 7 \mathrm{c}(11.31 \%)$. Diphosphatidylglycerol (DPG), phosphatidylglycerol (PG), phosphatidylethanolamine (PE), amino phospholipids (APL), and unidentified phospholipids (PL) are identified as the polar lipid. The major quinone is ubiquinone-9 (Q-9). The type strain is $\mathrm{WH} 53^{\mathrm{T}}\left(=\mathrm{DSM} 111628^{\mathrm{T}}=\mathrm{NCCB} 100808^{\mathrm{T}}\right)$, isolated from pacific oyster Crassostrea gigas collected from the Whilmshaven, Germany. DNA G+C content is $40.08 \mathrm{~mol} \%$. The genome size is 5,914,969 bp with 5120 coding sequences, 54 tRNA genes, and three rRNA operons. The complete genome and the $16 \mathrm{~S}$ rRNA sequence of strain $\mathrm{WH}_{53}{ }^{\mathrm{T}}$ were deposited at NCBI GenBank with accession numbers JAGSOY000000000 and MW888978, respectively.

Description of Zooshikella ganghwensis subsp. marina subsp. nov.

Zooshikella ganghwensis subsp. marina (ma.ri'na. L. fem. adj. marina of the sea, marine): Basonym: Zooshikella marina Ramaprasad et al. 2015. 
The description is identical to that given for Zooshikella marina by Ramaprasad et al. [11]. Type strain is JC $333^{\mathrm{T}}\left(=\mathrm{KCTC} 42659^{\mathrm{T}}=\mathrm{LMG} 28823^{\mathrm{T}}\right)$.

Description of Zooshikella ganghwensis subsp. ganghwaensis subsp. nov.

Zooshikella ganghwensis (gang.hwen'sis. N.L. fem. adj. ganghwensis, Ganghwa Island, Korea):

Basonym: Zooshikella ganghwensis Yi et al. 2003.

The description is identical to that given for Zooshikella ganghwensis by Yi et al. [9]. The type strain is JC2044 ${ }^{\mathrm{T}}\left(=\mathrm{IMSNU} 14003^{\mathrm{T}}=\mathrm{KCTC} 12044^{\mathrm{T}}=\mathrm{DSM} 15267^{\mathrm{T}}\right)$, and the subspecies was created on the basis of rule $40 \mathrm{~d}$ of the Bacteriological Code [66].

Supplementary Materials: The following are available online at https:/ /www.mdpi.com/article/ 10.3390/d13120641/s1, Figure S1: Two-dimensional thin-layer chromatogram of polar lipids extracted from (a) strain WH53T; (b) Zooshikella marina LMG 28823T; (c) Zooshikella ganghwensis DSM 15267T. Figure S2: Phylogenomic tree inferred from GBDP distances calculated from genome sequences showing relationships between strain WH53T and the closely related type strains based on Type (Strain) Genome Server (TYGS) (https:/ /tygs.dsmz.de/) (accessed on 3 November 2021). The number at the nodes are GBDP pseudo-bootstrap support values $>60 \%$ from 100 replications, with average branch support of $25.8 \%$. Table S1: Antimicrobial activity of Strain WH53T against human pathogens shown in MIC value (\%).

Author Contributions: Conceptualization, performed experiments, data analyses, manuscript drafting. H.P.; review and editing, data analyses, C.R. as equal work with H.P.; DNA-DNA hybridization, P.K.; electron microscopy, M.M.; pacific oyster samples preparation and technical support, P.J.S.; the project supervisor and manuscript editor, J.W. All authors have read and agreed to the published version of the manuscript.

Funding: This scholarship awarded by Konrad Adenauer Stiftung (KAS) in Germany https: / www. kas.de/en/web/begabtenfoerderung-undkultur/promotionsfoerderung.

Institutional Review Board Statement: Not applicable.

Data Availability Statement: The GenBank accession number for the 16S rRNA gene sequence of strain $\mathrm{WH} 53^{\mathrm{T}}$ is MW888978. Draft genome of strain $\mathrm{WH} 53^{\mathrm{T}}$ and Zooshikella marina $\mathrm{LMG} 28823^{\mathrm{T}}$ were deposited at NCBI/GenBank under the accession number JAGSOY000000000 and JAGSGA000000000, respectively.

Acknowledgments: The authors appreciate the excellent effort of technical assistance, Stephanie Schulz, Klaus Peter Conrad, Birte Trunkwalter, Wera Collisi, Ina Schleicher (for electron microscopy sample preparation), and Aileen Gollasch for recording the HRESIMS data. Special thanks to Jolanta Lulla for medium preparation.

Conflicts of Interest: The authors declare no conflict of interest.

\section{References}

1. Tortorella, E.; Tedesco, P.; Palma Esposito, F.; January, G.G.; Fani, R.; Jaspars, M.; De Pascale, D. Antibiotics from Deep-Sea Microorganisms: Current Discoveries and Perspectives. Mar. Drugs 2018, 16, 355. [CrossRef] [PubMed]

2. Nawaz, A.; Chaudhary, R.; Shah, Z.; Dufossé, L.; Fouillaud, M.; Mukhtar, H.J.M. An Overview on Industrial and Medical Applications of Bio-Pigments Synthesized by Marine Bacteria. Microorganisms 2021, 9, 11. [CrossRef] [PubMed]

3. Bruckner, A.W.J.I.I.S. Technology. Life-saving products from coral reefs. Issues Sci. Technol. 2002, 18, 39-44.

4. Soliev, A.B.; Hosokawa, K.; Enomoto, K. Bioactive Pigments from Marine Bacteria: Applications and Physiological Roles. Evid.-Based Complement. Altern. Med. 2011, 2011, 670349. [CrossRef]

5. Pawar, R.; Mohandass, C.; Rajasabapathy, R.; Meena, R.M. Molecular diversity of marine pigmented bacteria in the central Arabian Sea with special reference to antioxidant properties. Cah. Biol. Mar. 2018, 59, 409-420.

6. Baharum, S.; Beng, E.; Mokhtar, M. Marine microorganisms: Potential application and challenges. J. Biol. Sci. 2010, 10, 555-564. [CrossRef]

7. Podar, M.; Reysenbach, A.-L. New opportunities revealed by biotechnological explorations of extremophiles. Curr. Opin. Biotechnol. 2006, 17, 250-255. [CrossRef]

8. Liao, H.; Lin, X.; Li, Y.; Qu, M.; Tian, Y. Reclassification of the Taxonomic Framework of Orders Cellvibrionales, Oceanospirillales, Pseudomonadales, and Alteromonadales in Class Gammaproteobacteria through Phylogenomic Tree Analysis. mSystems 2020, 5, e00543-20. [CrossRef] [PubMed] 
9. Yi, H.; Chang, Y.-H.; Oh, H.W.; Bae, K.S.; Chun, J. Zooshikella ganghwensis gen. nov., sp. nov., isolated from tidal flat sediments. Int. J. Syst. Evol. Microbiol. 2003, 53, 1013-1018. [CrossRef]

10. Lee, J.S.; Kim, Y.-S.; Park, S.; Kim, J.; Kang, S.-J.; Lee, M.-H.; Ryu, S.; Choi, J.M.; Oh, T.-K.; Yoon, J.-H. Exceptional Production of both Prodigiosin and Cycloprodigiosin as Major Metabolic Constituents by a Novel Marine Bacterium, Zooshikella rubidus S1-1. Appl. Environ. Microbiol. 2011, 77, 4967-4973. [CrossRef]

11. Ramaprasad, E.V.V.; Bharti, D.; Sasikala, C.; Ramana, C.V. Zooshikella marina sp. nov. a cycloprodigiosin- and prodigiosinproducing marine bacterium isolated from beach sand. Int. J. Syst. Evol. Microbiol. 2015, 65, 4669-4673. [CrossRef] [PubMed]

12. Yamamoto, C.; Takemoto, H.; Kuno, K.; Yamamoto, D.; Tsubura, A.; Kamata, K.; Hirata, H.; Yamamoto, A.; Kano, H.; Seki, T.; et al. Cycloprodigiosin hydrochloride, a new $\mathrm{H}+/ \mathrm{Cl}$ - symporter, induces apoptosis in human and rat hepatocellular cancer cell lines in vitro and inhibits the growth of hepatocellular carcinoma xenografts in nude mice. Hepatology 1999, 30, 894-902. [CrossRef]

13. Boger, D.L.; Patel, M. Total synthesis of prodigiosin, prodigiosene, and desmethoxyprodigiosin: Diels-Alder reactions of heterocyclic azadienes and development of an effective palladium(II)-promoted 2,2'-bipyrrole coupling procedure. J. Org. Chem. 1988, 53, 1405-1415. [CrossRef]

14. Castro, A.J. Antimalarial Activity of Prodigiosin. Nature 1967, 213, 903-904. [CrossRef] [PubMed]

15. Beatriz, M.; Ricardo, P.-T. The Prodigiosins: A New Family of Anticancer Drugs. Curr. Cancer Drug Targets 2003, 3, 57-65. [CrossRef]

16. Han, S.B.; Kim, H.M.; Kim, Y.H.; Lee, C.W.; Jang, E.-S.; Son, K.H.; Kim, S.U.; Kim, Y.K. T-cell specific immunosuppression by prodigiosin isolated from Serratia marcescens. Int. J. Immunopharmacol. 1998, 20, 1-13. [CrossRef]

17. Jeong, H.; Yim, J.H.; Lee, C.; Choi, S.-H.; Park, Y.K.; Yoon, S.H.; Hur, C.-G.; Kang, H.-Y.; Kim, D.; Lee, H.H.; et al. Genomic blueprint of Hahella chejuensis, a marine microbe producing an algicidal agent. Nucleic Acids Res. 2005, 33, 7066-7073. [CrossRef] [PubMed]

18. Nakashima, T.; Miyazaki, Y.; Matsuyama, Y.; Muraoka, W.; Yamaguchi, K.; Oda, T. Producing mechanism of an algicidal compound against red tide phytoplankton in a marine bacterium $\gamma$-proteobacterium. Appl. Microbiol. Biotechnol. 2006, 73, 684-690. [CrossRef]

19. Alihosseini, F.; Ju, K.-S.; Lango, J.; Hammock, B.D.; Sun, G. Antibacterial Colorants: Characterization of Prodiginines and Their Applications on Textile Materials. Biotechnol. Prog. 2008, 24, 742-747. [CrossRef]

20. Haddix, P.L.; Jones, S.; Patel, P.; Burnham, S.; Knights, K.; Powell, J.N.; LaForm, A. Kinetic Analysis of Growth Rate, ATP, and Pigmentation Suggests an Energy-Spilling Function for the Pigment Prodigiosin of Serratia marcescens. J. Bacteriol. 2008, 190, 7453-7463. [CrossRef]

21. Gerber, N.N.; Gauthier, M.J. New prodigiosin-like pigment from Alteromonas rubra. Appl. Environ. Microbiol. 1979, 37, 1176-1179. [CrossRef]

22. Kawauchi, K.; Shibutani, K.; Yagisawa, H.; Kamata, H.; Nakatsuji, S.I.; Anzai, H.; Yokoyama, Y.; Ikegami, Y.; Moriyama, Y.; Hirata, H. A Possible Immunosuppressant, Cycloprodigiosin Hydrochloride, Obtained from Pseudoalteromonas denitrificans. Biochem. Biophys. Res. Commun. 1997, 237, 543-547. [CrossRef]

23. Bennett, J.W.; Bentley, R. Seeing Red: The Story of Prodigiosin. In Advances in Applied Microbiology; Academic Press: Cambridge, MA, USA, 2000; Volume 47, pp. 1-32. [CrossRef]

24. Yamamoto, D.; Uemura, Y.; Tanaka, K.; Nakai, K.; Yamamoto, C.; Takemoto, H.; Kamata, K.; Hirata, H.; Hioki, K. Cycloprodigiosin hydrochloride, H+/CL- symporter, induces apoptosis and differentiation in HL-60 cells. Int. J. Cancer 2000, 88, 121-128. [CrossRef]

25. Yamamoto, D.; Tanaka, K.; Nakai, K.; Baden, T.; Inoue, K.; Yamamoto, C.; Takemoto, H.; Kamato, K.; Hirata, H.; Morikawa, S.; et al. Synergistic Effects Induced by Cycloprodigiosin Hydrochloride and Epirubicin on Human Breast Cancer Cells. Breast Cancer Res. Treat. 2002, 72, 1-10. [CrossRef]

26. Kamata, K.; Okamoto, S.; Oka, S.-I.; Kamata, H.; Yagisawa, H.; Hirata, H. Cycloprodigiosin hydrocloride suppresses tumor necrosis factor (TNF) $\alpha$-induced transcriptional activation by NF-кB. FEBS Lett. 2001, 507, 74-80. [CrossRef]

27. Landwehr, W.; Kämpfer, P.; Glaeser, S.P.; Rückert, C.; Kalinowski, J.; Blom, J.; Goesmann, A.; Mack, M.; Schumann, P.; Atasayar, E.; et al. Taxonomic analyses of members of the Streptomyces cinnabarinus cluster, description of Streptomyces cinnabarigriseus sp. nov. and Streptomyces davaonensis sp. nov. Int. J. Syst. Evol. Microbiol. 2018, 68, 382-393. [CrossRef]

28. Kutzner, H.J.T.P. The Family Streptomycetaceae; Springer: New York, NY, USA, 1981. [CrossRef]

29. Shirling, E.B.; Gottlieb, D. Methods for characterization of Streptomyces species1. Int. J. Syst. Bacteriol. 1966, 16, 313-340. [CrossRef]

30. Humble, M.W.; King, A.; Phillips, I. API ZYM: A simple rapid system for the detection of bacterial enzymes. J. Clin. Pathol. 1977, 30, 275-277. [CrossRef]

31. Soto, A.; Zapardiel, J.; Soriano, F. Evaluation of API Coryne system for identifying coryneform bacteria. J. Clin. Pathol. 1994, 47, 756-759. [CrossRef]

32. Primahana, G.; Risdian, C.; Mozef, T.; Sudarman, E.; Köck, M.; Wink, J.; Stadler, M. Nonocarbolines A-E, $\beta$-Carboline Antibiotics Produced by the Rare Actinobacterium Nonomuraea sp. from Indonesia. Antibiotics 2020, 9, 126. [CrossRef]

33. Chaiya, L.; Matsumoto, A.; Wink, J.; Inahashi, Y.; Risdian, C.; Pathom-aree, W.; Lumyong, S. Amycolatopsis eburnea sp. nov., an actinomycete associated with arbuscular mycorrhizal fungal spores. Int. J. Syst. Evol. Microbiol. 2019, 69, 3603-3608. [CrossRef]

34. Hall, T.A. Bioedit: A user-friendly biological sequence alignment editor and analysis program for Windows 95/98/NT. Nucleic Acids Symp. Ser. 1999, 41, 95-98. 
35. Yoon, S.-H.; Ha, S.-M.; Kwon, S.; Lim, J.; Kim, Y.; Seo, H.; Chun, J. Introducing EzBioCloud: A taxonomically united database of 16S rRNA gene sequences and whole-genome assemblies. Int. J. Syst. Evol. Microbiol. 2017, 67, 1613-1617. [CrossRef] [PubMed]

36. Meier-Kolthoff, J.P.; Auch, A.F.; Klenk, H.-P.; Göker, M. Genome sequence-based species delimitation with confidence intervals and improved distance functions. BMC Bioinform. 2013, 14, 60. [CrossRef] [PubMed]

37. Meier-Kolthoff, J.P.; Hahnke, R.L.; Petersen, J.; Scheuner, C.; Michael, V.; Fiebig, A.; Rohde, C.; Rohde, M.; Fartmann, B.; Goodwin, L.A.; et al. Complete genome sequence of DSM 30083T, the type strain (U5/41T) of Escherichia coli, and a proposal for delineating subspecies in microbial taxonomy. Stand. Genom. Sci. 2014, 9, 2. [CrossRef]

38. Meier-Kolthoff, J.P.; Göker, M.; Spröer, C.; Klenk, H.P. When should a DDH experiment be mandatory in microbial taxonomy? Arch. Microbiol. 2013, 195, 413-418. [CrossRef]

39. Edgar, R.C. MUSCLE: Multiple sequence alignment with high accuracy and high throughput. Nucleic Acids Res. 2004, 32, 1792-1797. [CrossRef]

40. Stamatakis, A. RAxML version 8: A tool for phylogenetic analysis and post-analysis of large phylogenies. Bioinformatics 2014, 30, 1312-1313. [CrossRef]

41. Goloboff, P.A.; Farris, J.S.; Nixon, K.C. TNT, a free program for phylogenetic analysis. Cladistics 2008, 24, 774-786. [CrossRef]

42. Pattengale, N.D.; Alipour, M.; Bininda-Emonds, O.R.; Moret, B.M.; Stamatakis, A. How many bootstrap replicates are necessary? J. Comput. Biol. A J. Comput. Mol. Cell Biol. 2010, 17, 337-354. [CrossRef]

43. Swofford, D. PAUP*. Phylogenetic Analysis Using Parsimony (*and Other Methods); Version 4.0b10; Sinauer Associates: Sunderland, MA, USA, 2002.

44. Minnikin, D.E.; O’Donnell, A.G.; Goodfellow, M.; Alderson, G.; Athalye, M.; Schaal, A.; Parlett, J.H. An integrated procedure for the extraction of bacterial isoprenoid quinones and polar lipids. J. Microbiol. Methods 1984, 2, 233-241. [CrossRef]

45. Risdian, C.; Landwehr, W.; Rohde, M.; Schumann, P.; Hahnke, R.L.; Spröer, C.; Bunk, B.; Kämpfer, P.; Schupp, P.J.; Wink, J. Streptomyces bathyalis sp. nov., an actinobacterium isolated from the sponge in a deep sea. Antonie Van Leeuwenhoek 2021, 114, 425-435. [CrossRef] [PubMed]

46. Sasser, M. Identification of Bacteria by Gas Chromatography of Cellular Fatty Acids; MIDI Tech. Note 101; MIDI Inc.: Newark, DE, USA, 1990.

47. Wick, R.R.; Judd, L.M.; Gorrie, C.L.; Holt, K.E. Unicycler: Resolving bacterial genome assemblies from short and long sequencing reads. PLoS Comput. Biol. 2017, 13, e1005595. [CrossRef]

48. Lee, I.; Chalita, M.; Ha, S.-M.; Na, S.-I.; Yoon, S.-H.; Chun, J. ContEst16S: An algorithm that identifies contaminated prokaryotic genomes using 16S RNA gene sequences. Int. J. Syst. Evol. Microbiol. 2017, 67, 2053-2057. [CrossRef]

49. Tatusova, T.; DiCuccio, M.; Badretdin, A.; Chetvernin, V.; Nawrocki, E.P.; Zaslavsky, L.; Lomsadze, A.; Pruitt, K.D.; Borodovsky, M.; Ostell, J. NCBI prokaryotic genome annotation pipeline. Nucleic Acids Res. 2016, 44, 6614-6624. [CrossRef] [PubMed]

50. Aziz, R.K.; Bartels, D.; Best, A.A.; DeJongh, M.; Disz, T.; Edwards, R.A.; Formsma, K.; Gerdes, S.; Glass, E.M.; Kubal, M.; et al. The RAST Server: Rapid Annotations using Subsystems Technology. BMC Genom. 2008, 9, 75. [CrossRef]

51. Medema, M.H.; Blin, K.; Cimermancic, P.; de Jager, V.; Zakrzewski, P.; Fischbach, M.A.; Weber, T.; Takano, E.; Breitling, R. antiSMASH: Rapid identification, annotation and analysis of secondary metabolite biosynthesis gene clusters in bacterial and fungal genome sequences. Nucleic Acids Res. 2011, 39, W339-W346. [CrossRef] [PubMed]

52. Blin, K.; Shaw, S.; Steinke, K.; Villebro, R.; Ziemert, N.; Lee, S.Y.; Medema, M.H.; Weber, T. antiSMASH 5.0: Updates to the secondary metabolite genome mining pipeline. Nucleic Acids Res. 2019, 47, W81-W87. [CrossRef]

53. Meier-Kolthoff, J.P.; Göker, M. TYGS is an automated high-throughput platform for state-of-the-art genome-based taxonomy. Nat. Commun. 2019, 10, 2182. [CrossRef]

54. Meier-Kolthoff, J.P.; Carbasse, J.S.; Peinado-Olarte, R.L.; Göker, M. TYGS and LPSN: A database tandem for fast and reliable genome-based classification and nomenclature of prokaryotes. Nucleic Acids Res. 2021, 10, 2182. [CrossRef]

55. Lefort, V.; Desper, R.; Gascuel, O. FastME 2.0: A Comprehensive, Accurate, and Fast Distance-Based Phylogeny Inference Program. Mol. Biol. Evol. 2015, 32, 2798-2800. [CrossRef] [PubMed]

56. Arkin, A.P.; Cottingham, R.W.; Henry, C.S.; Harris, N.L.; Stevens, R.L.; Maslov, S.; Dehal, P.; Ware, D.; Perez, F.; Canon, S.; et al. KBase: The United States Department of Energy Systems Biology Knowledgebase. Nat. Biotechnol. 2018, 36, 566-569. [CrossRef]

57. Seemann, T. Prokka: Rapid prokaryotic genome annotation. Bioinformatics 2014, 30, 2068-2069. [CrossRef]

58. Price, M.N.; Dehal, P.S.; Arkin, A.P. FastTree 2-Approximately Maximum-Likelihood Trees for Large Alignments. PLoS ONE 2010, 5, e9490. [CrossRef] [PubMed]

59. Yoon, S.-H.; Ha, S.-m.; Lim, J.; Kwon, S.; Chun, J. A large-scale evaluation of algorithms to calculate average nucleotide identity. Antonie Van Leeuwenhoek 2017, 110, 1281-1286. [CrossRef] [PubMed]

60. Qin, Q.-L.; Xie, B.-B.; Zhang, X.-Y.; Chen, X.-L.; Zhou, B.-C.; Zhou, J.; Oren, A.; Zhang, Y.-Z. A Proposed Genus Boundary for the Prokaryotes Based on Genomic Insights. J. Bacteriol. 2014, 196, 2210-2215. [CrossRef] [PubMed]

61. Rodriguez-R, L.M.; Konstantinidis, K.J.M.M. Bypassing Cultivation To Identify Bacterial Species: Culture-independent genomic approaches identify credibly distinct clusters, avoid cultivation bias, and provide true insights into microbial species. ASM 2014, 9, 111-118. [CrossRef]

62. Ziemke, F.; Höfle, M.G.; Lalucat, J.; Rossellö-Mora, R. Reclassification of Shewanella putrefaciens Owens genomic group II as Shewanella baltica sp. nov. Int. J. Syst. Bacteriol. 1998, 48, 179-186. [CrossRef] 
63. Khosravi Babadi, Z.; Ebrahimipour, G.; Wink, J.; Narmani, A.; Risdian, C. Isolation and identification of Streptomyces sp. Act4Zk, a good producer of Staurosporine and some derivatives. Lett. Appl. Microbiol. 2021, 72, 206-218. [CrossRef]

64. Chun, J.; Oren, A.; Ventosa, A.; Christensen, H.; Arahal, D.R.; da Costa, M.S.; Rooney, A.P.; Yi, H.; Xu, X.-W.; De Meyer, S.; et al. Proposed minimal standards for the use of genome data for the taxonomy of prokaryotes. Int. J. Syst. Evol. Microbiol. 2018, 68, 461-466. [CrossRef]

65. Wayne, L.G.; Brenner, D.J.; Colwell, R.R.; Grimont, P.A.D.; Kandler, O.; Krichevsky, M.I.; Moore, L.H.; Moore, W.E.C.; Murray, R.G.E.; Stackebrandt, E.; et al. Report of the Ad Hoc Committee on Reconciliation of Approaches to Bacterial Systematics. Int. J. Syst. Evol. Microbiol. 1987, 37, 463-464. [CrossRef]

66. International Code of Nomenclature of Prokaryotes. Int. J. Syst. Evol. Microbiol. 2019, 69, S1-S111. [CrossRef] [PubMed] 